JURNAL RESPIRASI

$J R$

Vol. 1 No. 3 September 2015

\title{
TB MDR Primer dengan Limfadenitis TB pada Wanita SLE
}

\author{
Ika Yunita Sari, Tutik Kusmiati \\ Departemen Pulmonologi dan Ilmu Kedokteran Respirasi, Fakultas Kedokteran Universitas Airlangga/RSUD Dr. Soetomo
}

\begin{abstract}
Background: Primary resistance is the resistance that occurs in patients who have never received treatment OAT or had ever received treatment OAT is less than 1 month. The incidence of primary MDR in Central Java in $20062.07 \%$. Extrapulmonary TB about $15-20 \%$ of all cases of TB, and TB lymphadenitis is the highest form (35\% of all extrapulmonary TB). Patients with decreased immune systems (SLE) can increase the incidence of TB. Research in Spain get 6x higher TB incidence in patients with SLE. Case: We present the case of 19 year old woman SLE who received treatment for 11 months whose came with shortness of breath and chronic cough since 2 month prior to admission. In physical examination we found right and left submandibula lymphonodi enlargement as solid, slightly mobile nodule with diameter $3 \mathrm{~cm}$. Chest $\mathrm{X}$ ray showed lung inflammation which suspicion of specific process and minimal left pleural effusion, and concluded as pulmonary TB. FNAB confirmed lymphadenitis TB with granulomatous inflammation. One of AFB result is positive and Gene Xpert is MTB positive with rifampicin resistant that make this patient categorized as primary MDR TB with lymphadenitis TB. This patient received Pirazinamid $1500 \mathrm{mg}$, Ethambutol $800 \mathrm{mg}$, Kanamicin $750 \mathrm{mg}$, Levofloxacin 750 mg, Ethionamide 500 mg, Cicloserin $500 \mathrm{mg}$, and B6 $100 \mathrm{mg}$. Conclusion: MDR TB in general occur in patients with a history of OAT previous TB (MDR TB secondary). Primary MDR TB with lymphadenitis tb is a rare case, but can occur on the condition that decreases the immune system, one of SLE. This involves multiple immune disorders caused by the use of long-term immunosuppressive therapy.
\end{abstract}

Key words: primary resistance, lymphadenitis TB, SLE

Correspondence: Ika Yunita Sari, Departemen Pulmonologi dan Ilmu Kedokteran Respirasi, Fakultas Kedokteran Universitas Airlangga/ RSUD Dr. Soetomo. Jl. Mayjen. Prof. Dr. Moestopo 6-8 Surabaya 60286. E-mail: dr.ika_yunita@yahoo.com

\section{PENDAHULUAN}

Tuberkulosis merupakan masalah kesehatan masyarakat yang penting di dunia ini. Pada tahun 1992, World Health Organization (WHO) telah mencanangkan TB sebagai Global Emergency. Jumlah kasus terbanyak di Asia Tenggara (35\%), Afrika (30\%) dan Pasifik Barat (20\%). Pada tahun 2009, diperkirakan kasus TB MDR sebanyak 250.000 kasus, tetapi hanya $12 \%$ atau 30.000 kasus yang sudah terkonfirmasi. ${ }^{1}$

Tuberkulosis dapat melibatkan berbagai sistem organ di tubuh. Meskipun TB pulmoner adalah yang paling banyak, TB ekstrapulmoner juga merupakan salah satu masalah klinis yang penting. Istilah TB ekstrapulmoner digunakan pada tuberkulosis yang terjadi di luar paru-paru. Berdasarkan epidemiologi TB ekstrapulmoner merupakan $15-20 \%$ dari semua kasus TB, dimana limfadenitis TB merupakan bentuk terbanyak (35\% dari semua TB ekstrapulmoner). ${ }^{2}$
Multi-Drug Resistance (MDR) menjadi masalah kesehatan masyarakat di sejumlah negara dan merupakan hambatan terhadap program pengendalian TB secara global. Kekebalan kuman TB terhadap obat anti tuberculosis (OAT) sebenarnya telah muncul sejak lama. MDR TB muncul seiring dengan dimulainya penggunaan rifampisin secara luas sejak tahun 1970an. Kekebalan ini dimulai dari yang sederhana yaitu monoresisten, poliresisten sampai dengan extensive drug resistance (XDR). ${ }^{3}$

Pada akhir tahun 2008 diperkirakan 510.000 kasus TB didunia menjadi MDR. Berkembangnya kasus TB yang menjadi MDR ini pada umumnya terjadi karena manajemen yang tidak tepat dari penyediaan obat-obat anti TB, pengobatan TB yang tidak tepat, dan mudahnya transmisi penyakit di masyarakat yang padat penduduk. ${ }^{4}$

Laporan WHO tahun 2007 menyatakan persentase resistensi primer di seluruh dunia telah terjadi poliresistensi $17,0 \%$, monoresistensi terdapat 10,3\%, dan Tuberculosis - 
Multidrug Resistant (TB-MDR) sebesar 2,9\%. Resistensi primer terjadi pada pasien yang sebelumnya tidak pernah mendapat pengobatan OAT atau telah mendapatkan OAT kurang dari 1 bulan. ${ }^{1}$ Kontak penularan M. tuberculosis secara droplet yang telah mengalami resistensi obat akan menciptakan kasus baru pasien TB yang resistensi primer, pada akhirnya mengarah pada kasus multi-drug resistance (MDR). Data awal survey resistensi obat lini pertama yang dilakukan di Jawa Tengah pada tahun 2006, menunjukkan angka TB MDR pada kasus baru yaitu 2,07\%, angka ini meningkat pada pasien yang pernah diobati sebelumnya yaitu $16,3 \%$. 6,7

Insiden penyakit TB pada penyakit dengan sistem imun yang menurun saat ini mengalami tren yang meningkat, angka insiden penyakit TB terus meningkat pada penyakit dengan sistem imun yang menurun, salah satunya adalah SLE. Tingginya prevalensi TB pada SLE disebabkan oleh kelainan imunitas yang multipel dan penggunaan terapi imunosupresi pada pasien tersebut. Kelainan imunologi pada SLE seperti defisiensi komplemen, asplenia fungsional, perubahan sistim fagosit (makrofag alveolar), dan defisiensi fungsional aktivitas sel $\mathrm{T}$, meningkatkan kerentanan terhadap infeksi Mycobacterium. Studi Spanish membandingkan kejadian TB pada SLE dengan populasi umum dan mendapatkan insiden TB 6x lebih tinggi pada pasien SLE. ${ }^{8}$ Berikut ini kami laporkan kasus TB MDR primer dengan limfadenitis TB pada wanita SLE.

\section{KASUS}

Wanita Ny. E 19 tahun, berpendidikan mahasiswa, dirawat di Tropik Wanita RSUD Dr. Soetomo dengan keluhan utama sesak napas disertai panas badan sejak 1 minggu yang lalu. Penanganan selama rawat inap, pasien MRS di tropik wanita dengan keluhan utama sesak napas disertai panas badan sejak 1 minggu yang lalu. Saat dirawat di tropik wanita pasien didiagnosa SLE + CAP + TB paru dalam terapi kategori 1 fase intensif + hipoalbumin. Pasien mendapat terapi infus PZ 14 tetes per menit, ceftriaxone 2 ' 1 gram, omeprazole 2 ' 1 , methyl prednisolon $4 \mathrm{mg}$ 0-0, cavit D3 3x1, parasetamol 3x500 mg, OAT kategori 1 (3 tablet 4 FDC), albumin 20\% 100 cc dalam 24 jam. Pasien dirawat selama 4 hari di tropik wanita. Dalam perjalanannya kondisi pasien membaik, tidak didapatkan adanya sesak napas dan panas badan. Pada pemeriksaan darah empat hari MRS didapatkan penurunan leukosit. Terapi saat pasien keluar dari rumah sakit yaitu: cefixime 2 ' $100 \mathrm{mg}$, omeprazole $220 \mathrm{mg}$, methyl prednisolone $4 \mathrm{mg}-0-0$, cavit D3 1 ' 1, domperidone 3x1, OAT kategori 1 (3 tablet 4 FDC). Berdasarkan pemeriksaan foto thoraks didapatkan gambaran keradangan paru yang dapat merupakan proses spesifik dan efusi pleura kiri minimal (lihat Gambar 1).

SLE ditegakkan karena memenuhi 4 dari 11 kriteria The American College of Rheumatology tahun 1997 yaitu adanya oral ulcer, fotosensitiviti, arthralgia, malar rash. Pasien mendapatkan pengobatan SLE di poli rematologi
RSUD Dr. Soetomo sejak 10 bulan sebelum masuk rumah sakit (SMRS) dengan tenggang waktu selama

10 bulan kurang 17 hari. Pasien mendapatkan terapi methyl prednisolon $8 \mathrm{mg}$ (sehari sekali) selama 1 bulan, diturunkan hingga 4 mg sehari sekali. Saat pertama kali berobat di poli rematologi pasien mengeluh badan sering lemas, nyeri pada persendian, rambut rontok, mata pasien silau jika terkena cahaya matahari. TB paru ditegakkan berdasarkan adanya gejala klinis yaitu batuk 2 bulan dengan dahak berwarna putih, penurunan nafsu makan, penurunan berat badan, keringat malam. Karena didapatkan adanya gejala cardinal sign TB, maka dilakukan pemeriksaan foto thorax dan sputum BTA. Limfadenitis TB ditegakkan berdasarkan adanya pembesaran kelenjar getah bening di submandibula kanan dan kiri diameter $3 \mathrm{~cm}$, batas kurang tegas, mobile terbatas, padat kenyal, tidak nyeri sejak 6 bulan yang lalu. Enam hari SMRS pemeriksaan FNAB didapatkan hasil secara mikroskopis: hapusan menunjukkan kelompok sel-sel epitheloid membentuk granuloma dengan latar belakang bahan nekrotik luas. Kesimpulan yaitu radang granulomatik sesuai tuberculosis. CAP ditegakkan berdasarkan adanya penambahan infiltrat, keluhan sesak nafas, batuk berdahak dan panas badan memberat sejak

1 minggu sebelum masuk rumah sakit. Pada pemeriksaan darah lengkap dan kimia klinik didapatkan peningkatan leukosit, granulosit dan CRP.

Berdasarkan anamnesa didapatkan adanya batuk sejak dua bulan SMRS, dengan dahak yang berwarna putih tanpa disertai batuk darah. Didapatkan penurunan nafsu makan (+) sejak 6 bulan yang lalu. Penurunan berat badan (+) sejak 6 bulan yang lalu (55 kg menjadi $41 \mathrm{~kg}$ ). Keringat malam (+). Pasien mengeluh terdapat benjolan di leher kanan dan kiri sejak 6 bulan yang lalu, benjolan tidak nyeri dan semakin membesar. Teman satu kost pasien adalah seorang penderita TB paru putus berobat (menurut keterangan pasien, teman satu kost hanya menjalani pengobatan selama 4 bulan kemudian dihentikan sendiri). Mereka tinggal serumah, tetapi berbeda kamar selama 2 tahun. Tetangga pasien (selisih 2 rumah) mengeluh sering batuk-batuk hingga batuk berdarah dan mendapatkan obat TB paru dari puskesmas. Nenek pasien adalah seorang penderita TB paru, tinggal serumah dengan pasien selama satu tahun. Nenek pasien meninggal tahun 2000 di RSUD Dr. Soetomo karena sakit paru-paru. Saat berinteraksi dengan teman satu kost, tetangga atau nenek, pasien tidak pernah memakai masker. Pasien tinggal di sebuah perkampungan dengan suasana padat penduduk. Pasien jarang membuka jendela kamarnya untuk mendapatkan sinar matahari. Menurut keterangan ibu pasien, rumah terkesan lembab dan ventilasi udara kurang. Pada pasien didapatkan adanya riwayat kontak dengan penderita TB drop out dan didapatkan pemeriksaan $\mathrm{BTA}+1$, pada pasien kami curigai menderita TB MDR, maka kami lakukan pemeriksaan GeneXpert tiga hari SMRS, selain itu pada pasien ini juga didapatkan penyakit imunocompromised yaitu SLE, sehingga pasien ini rentan terhadap TB MDR. Berdasarkan pemeriksaan Gene Xpert didapatkan M.tb positif, rifampisin resisten. 
Pasien kontrol ke poli TB MDR RSUD Dr. Soetomo empat hari setelah MRS untuk menerima hasil Gene Xpert, dan telah dinyatakan positif MDR dan keesokan harinya pasien memulai pengobatan TB. Sebelum mendapatkan terapi MDR, pasien diperiksakan darah lengkap, kimia klinik dan serum elektrolit. Pasien juga dikonsultasikan ke bagian THT dan jantung. Dari pemeriksaan THT dan jantung, tidak didapatkan adanya kontra indikasi pemberian OAT MDR TB. Penderita dikategorikan sebagai TB MDR primer dengan terapi: Pirazinamid $1500 \mathrm{mg}$, Ethambutol $800 \mathrm{mg}$, Kanamisin $750 \mathrm{mg}$, Levofloxacin $750 \mathrm{mg}$, Etionamide 500 mg, Cicloserin 500 mg, B6 100 mg.

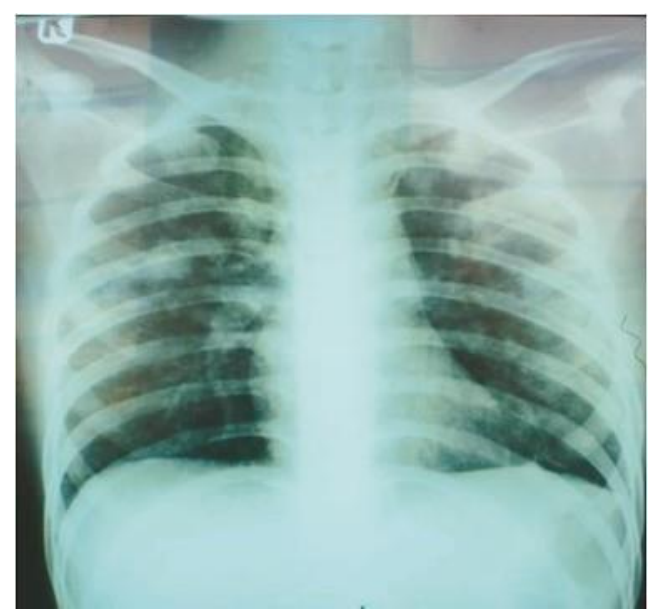

Gambar 1. Foto Thorak

\section{SEQUENCE OF EVENT}

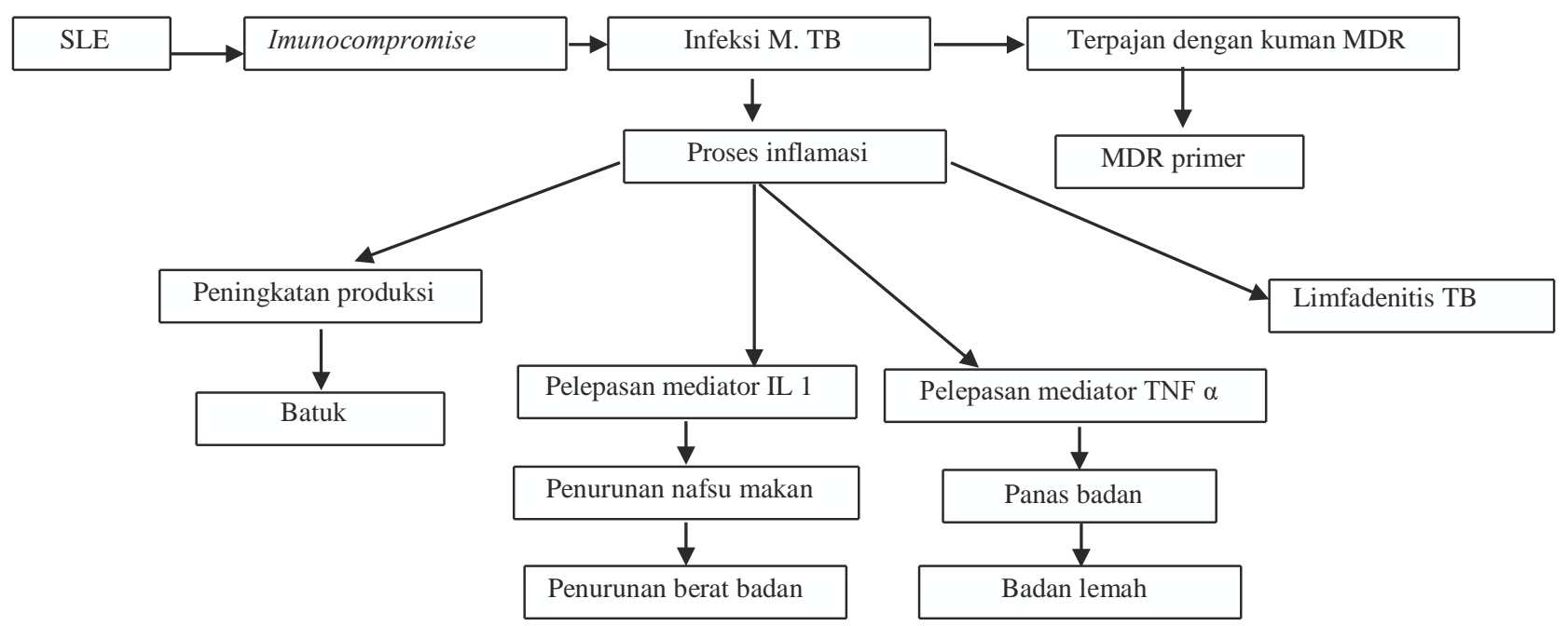

\section{DISKUSI}

Resistensi Primer adalah resistensi yang terjadi pada pasien yang belum pernah mendapat pengobatan OAT atau sudah pernah mendapat pengobatan tetapi kurang dari 1 bulan. Pada resistensi ini terjadi oleh karena individu terpajan dengan kuman yang telah resisten terhadap obat TB atau disebut resistance among new cases. ${ }^{3}$ Strategi diagnosis TB MDR adalah semua suspek TB MDR bisa mengakses pemeriksaan laboratorium untuk uji kepekaan M.tb secara baku dan bermutu. Pemeriksaan laboratorium untuk uji kepekaan M.tb dilakukan dengan metode standar yang tersedia di Indonesia yaitu: (a) Pemeriksaan uji kepekaan M.tb dengan metode konvensional menggunakan media padat (Lowenstein Jensen/LJ) atau media cair (MGIT); (b) Tes cepat (Rapid Test); (c) Menggunakan cara Hain atau GeneXpert.

Saat ini pemeriksaan uji kepekaan M.tb secara cepat (rapid test) sudah direkomendasikan oleh WHO untuk digunakan sebagai penapisan. Metode yang tersedia adalah: (a) Line Probe Assay (LPA) yaitu pemeriksaan molekuler yang didasarkan pada PCR, dikenal sebagai Hain Test/Genotype MDR-TB plus, hasil pemeriksaan dapat diperoleh dalam waktu kurang lebih 24 jam, hasil penelitian menunjukkan bahwa sebagian besar dari M.tb yang resisten terhadap rifampisin $(\mathrm{R})$ ternyata juga resisten terhadap isoniazid $(\mathrm{H})$ sehingga tergolong TB MDR; (b) Gene Xpert, merupakan tes molekuler berbasis PCR, merupakan tes amplifikasi asam nukleat secara automatis sebagai saran deteksi TB dan uji kepekaan untuk rifampisin, dan hasil pemeriksaan dapat diketahui dalam waktu kurang lebih 1-2 jam. 
Klasifikasi TB MDR berdasarkan lokasi yaitu; (a) Paru, Apabila kelainan ada di dalam parenkim paru, (b) Ekstra Paru, Apabila kelainan ada di luar parenkim paru. Jika Berdasarkan pada riwayat pengobatan sebelumnya yaitu; (a) Pasien baru, Pasien yang belum pernah mendapat pengobatan dengan OAT atau pernah diobati menggunakan OAT kurang dari 1 bulan; (b) Pasien dengan Pengobatan ulangan, pasien yang kambuh (relaps), pasien yang mempunyai kasus kronik/gagal dan pasien yang telah melakukan pengobatan setelah putus berobat (defaulter).

Pada kasus ini pasien dikategorikan sebagai pasien TB MDR primer karena pasien pernah mendapatkan OAT kurang dari satu bulan ( 9 hari) dan terpajan oleh penderita TB paru yaitu teman satu kost, tetangga dan nenek pasien. Berdasarkan kriteria suspek TB MDR pasien termasuk dalam kelompok nomer delapan yaitu pasien suspek TB dengan keluhan yang tinggal dekat pasien TB resisten obat ganda konfirmasi termasuk petugas kesehatan yang bertugas di bangsal TB resisten obat ganda respon klinis terhadap pengobatan TB dengan OAT lini pertama. Untuk menegakkan diagnose TB MDR primer pada kasus ini telah dilakukan pemeriksaan Gene Xpert, dan didapatkan hasil M.tb positif, rifampisin resisten.

Penyebab resistensi obat TB atau drug resistance TB (DR-TB) secara umum dibagi menjadi 3 faktor, yaitu yang pertama faktor kuman, kedua klinis, ketiga program. Pada perspektif kuman, DR-TB terjadi oleh karena adanya mutasi genetic yang menimbulkan obat tidak efektif melawan kuman yang mengalami mutasi. Dari perspektif klinis dan program, DR-TB terjadi karena terapi yang tidak memadai/ adekuat atau kurang baik. ${ }^{3}$

Pada awalnya resistensi obat TB dapat terjadi oleh karena kesalahan manusia (human error) yaitu meliputi kesalahan dalam penatalaksanaan kasus, manajemen logistik, peresepan obat. Jadi terdapat 3 faktor utama penyebab terjadinya pengobatan TB yang tidak adekuat yang pada akhirnya memudahkan terjadinya kasus resitensi obat TB, yaitu, (a) faktor penyedia sarana dan prasarana kesehatan; (b) faktor obat; dan (c) faktor pasien sendiri. ${ }^{3}$ Uraian selengkapnya dapat dilihat pada tabel 1 berikut ini.

\section{Mekanisme Resistensi}

Resistensi natural adalah resistensi yang ditemukan pada strain liar yang timbul sebagai hasil multiplikasi berkelanjutan kuman-kuman tersebut. Populasi ini tidak signifikan. Resistensi pada strain liar tersebut harus terpapar suatu obat antituberkulosis agar terekspresi secara fenotip. Bila resistensi terjadi karena terapi yang tidak adekuat (monoterapi) maka resistensi yang terjadi bersifat didapat atau acquired resistance atau juga disebut resistensi sekunder. Jika pasien TB dengan resistensi sekunder ini menularkan pada orang lain yang belum mendapat OAT, maka resistensi yang terjadi adalah resistensi inisial atau resistensi primer. ${ }^{3,4}$

Pada kasus ini mekanisme resistensi obat TB terjadi karena faktor kuman. Mutasi genetik yang menimbulkan obat tidak efektif elawan kuman yang mengalami mutasi. Selain itu pasien menderita SLE yang telah mendapatkan pengobatan kortikosteroid selama 11 bulan. Glukokortikoid merangsang imunodesfisiensi seluler sehingga meningkatkan risiko infeksi virus, bakteri, jamur dan parasit.

Pengobatan pasien TB MDR menggunakan paduan OAT yang terdiri dari OAT lini pertama dan lini kedua, yang dibagi dalam 5 kelompok berdasar potensi dan efikasinya. ${ }^{1}$ Uraian selengkapnya dapat dilihat pada tabel 2 .

Levofloxacin adalah golongan fluoroquinolon, mempunyai efek bakterisidal kuat terhadap M.tb. Dosis 500-1000 mg per hari pada pasien dewasa. Dosis ratarata $750 \mathrm{mg}$ bentuk sediaan oral dan intravena. Efek samping Levoflokxacin adalah mual, pusing, insomnia, tremor. Efek yang jarang terjadi adalah rupture tendon, arthralgia, dan prolong QT. ${ }^{5}$ Ethambutol mempunyai efek bakteriostatik terhadap kuman M.tb. Dosis dewasa 15-25 $\mathrm{mg} / \mathrm{kg} \mathrm{BB} /$ hari. Bentuk sediaan oral, tidak tersedia bentuk parenteral. Efek samping obat yang bisa terjadi adalah neuritis retrobulbar. ${ }^{5}$

Pirazinamid adalah derivate nikotinamid. Dosis dewasa $25 \mathrm{mg} / \mathrm{kg} \mathrm{BB} /$ hari, dosis maksimal 2 gram/hari. Efek samping obat adalah gout (hiperurisemia) dan artralgia, hepatotoksik, rash pada kulit, fotosensitivitas, dan gangguan gastrointestinal. ${ }^{5}$ Kanamycin adlah golongan aminoglikosida. Mempunyai efek bakterisidal terhadap kuman MTB. Dosis dewasa $15 \mathrm{mg} / \mathrm{kg} \mathrm{BB} / \mathrm{hari}$. Efek samping ototoksisitas dan toksisitas vestibular. Penggunaan kanamycin harus dengan monitoring fungsi ginjal. ${ }^{5}$ Ethionamid adalah derivate asam isonikotinat. Bersifat bakterisidal lemah. Dosis 15-20 mg/kg BB/ hari. Bentuk sediaan tablet salut $250 \mathrm{mg}$. Efek samping

Tabel 1. Penyebab terapi OAT tidak adekuat

\begin{tabular}{|c|c|c|}
\hline $\begin{array}{c}\text { Penyelenggara Kesehatan: Regimen } \\
\text { yang tidak adekuat }\end{array}$ & $\begin{array}{c}\text { Obat: (Ketersediaan/Kualitas yang } \\
\text { tidak adekuat) }\end{array}$ & $\begin{array}{c}\text { Pasien konsumsi obat yang tidak } \\
\text { adekuat }\end{array}$ \\
\hline $\begin{array}{l}\text { - Pedoman yang tidak sesuai } \\
\text { - Pedoman pelatihan yang kurang } \\
\text { - Tidak adanya pengawasan pengobatan }\end{array}$ & $\begin{array}{l}\text { - Beberapa Kualitas yang buruk } \\
\text { Ketidaktersediaan beberapa obat } \\
\text { Penyimpanan yang buruk } \\
\text { - Kesalahan dosis/kombinasi }\end{array}$ & $\begin{array}{l}\text { · Kepatuhan yang buruk. } \\
\text { · Kurangnya informasi · } \\
\text { Kurangnya biaya } \\
\text { - Kekurangan transportasi } \\
\text { - Efek samping obat }\end{array}$ \\
\hline $\begin{array}{l}\text { Sedikitnya pembiayaan program TB } \\
\text { control }\end{array}$ & - & $\begin{array}{l}\text { Hambatan social } \\
\text { Malabsorbsi }\end{array}$ \\
\hline
\end{tabular}


Tabel 2. Paduan OAT

\begin{tabular}{lll}
\hline Golongan & \multicolumn{1}{c}{ Jenis } & \multicolumn{1}{c}{ Obat } \\
\hline Golongan 1 & Obat lini pertama & Isoniazid (H) Pirazinamid (Z) \\
Golongan 2 & Obat suntik lini kedua & Rifampisin (R) Streptomisin (S) \\
& & Etambutol (E) \\
Golongan 3 & Golongan Fluoroquinolone & Kanamisin (Km) \\
& & Amikasin (Am) \\
& & Kapreomisin (Cm) \\
Golongan 4 & Obat bakteriostatik lini kedua & Levofloksasin (Lfx) \\
& & Moksifloksasin (Mfx) \\
& & Ofloksasin (Ofx) \\
Golongan 5 & Obat yang belum terbukti efikasinya dan tidak & Etionamid (Eto) Terizidon (Trd) \\
& direkomendasikan oleh WHO & Protionamid (Pto) Para amino salisilat (PAS) \\
& & Sikloserin (Cs) \\
& & Linezolid (Lzd) \\
& & Amoksisilin /Asam klavulanat (Amx/Clv) \\
& & Clarithromisin (Clr)
\end{tabular}

obat diantaranya adalah keluhan gastrointestinal dan anoreksia, hepatotoksik, efek endokrin (ginekomasti, acne, impotensi, menstruasi yang tidak teratur, hipotiroidisme), neurotoksisitas. ${ }^{5}$ Cycloserin termasuk analog D-alanin. Bersifat bakteriostatik dengan inhibisi sintesis dinding sel. Dosis 10-15 mg/kgBB/hari. Bentuk sediaan kapsul $250 \mathrm{mg}$. Efek samping obat adalah toksisitas CNS (kejang, depresi, psikosis). ${ }^{5}$

Capreomycin adalah kelas cyclic polipeptida. Mempunyai efek bakterisidal terhadap MTB sangat kuat, dosis dewasa $15 \mathrm{mg} / \mathrm{kgBB} /$ hari. Bentuk sediaan vial 1 gram untuk intramuscular maupun intravena, efek samping diantaranya adalah nefrotoksik, ototoksik, nyeri pada daerah injeksi intramuscular, kelainan elektrolit. ${ }^{5}$ Pada pasien ini regimen OAT yang diberikan adalah Pirazinamid $1500 \mathrm{mg}$, Ethambutol $800 \mathrm{mg}$, Levofloxacin $750 \mathrm{mg}$, Kanamycin 750 mg, Ethionamid 500 mg, Cyclocerin 500 $\mathrm{mg}$ dan vit. B6 $100 \mathrm{mg}$.

\section{Lymfadenitis TB}

Infeksi primer terjadi setelah seseorang menghirup mikobakterium tuberculosis, setelah melalui barier mukosilier saluran napas, basil TB akan mencapai alveoli. Paru merupakan pintu utama masuknya kuman tuberkulosis ke dalam tubuh. Kuman yang bersarang di paru bisa menimbulkan infeksi lokal atau sarang primer. Sarang primer ini bisa tmbul di bagian mana saja dalam paru. ${ }^{10}$ Kuman menyebar melalui aliran limfe menuju ke kelenjar getah bening hilus, terjadi proses limfangitis lokal. Peradangan ini diikuti pembesaran kelenjar getah bening di hilus (limfadenitis regional). Komposisi ini disebut dengan komplek primer. ${ }^{12}$

Jika infeksi tidak dapat diatasi oleh sistem imun lokal, kuman dapat menyebar perkontinuatum, bronkogen, limfogen dan hematogen. Kuman dalam makrofag yang lemah menyebar menuju jaringan dan organ tubuh lainnya.
Kuman yang mencapai aliran darah dapat menyebar ke paru bagian atas atau organ lainnya seperti ginjal, otak dan tulang. Beberapa organ ini merupakan tempat ideal bagi kuman karena tekanan oksigen yang ideal dan rendahnya perfusi aliran darah. ${ }^{13}$

Lymphadenitis Tuberculosa sebagaimana halnya seperti Tuberculosa Paru maka gejala umum TBC senantiasa dapat pula ditemukan, seperti misalnya subfebril, nafsu makan turun, berat badan turun, lemah badan, keringat malam. ${ }^{13}$ Penampakan fisik dari lymfadenitis TBC superficial diklasifikasikan dalam 5 stadium oleh Jones dan Campbell yaitu, ${ }^{13}$ (a) Stadium I: Pembesaran KGB dengan konsistensi kenyal, mobile/mudah digerakan, terpisah dengan nodul yang lain, hal ini menunjukan nonspecific reaksi hyperplasia; (b) Stadium 2: lebih besar dari stadium 1 dengan konsistensi yang kenyal, melekat dengan jaringn sekitarnya/berkonfluensi; (c) Stadium 3: perlunakan sentral diakibatkan karena terbentuknya abses; (d) Stadium 4: bentukan collar stud absess/warna kemerahan diatas kulit yang mengalami absesa; (e) Stadium 5: pembentukan sinus yang mengalirkan sekret bernanah.

Ketika penegakan diagnosa lymphadenitis TB meragukan, dapat digunakan prosedur biopsi untuk pemeriksaan histologih, kultur dan PCR. Total exsisi biopsi seharusnya dilakukan, sebab apabila kita melakukan biopsi yang incomplit sering menyebakan timbulnya ulserasi dan pembentukan sinus. ${ }^{12,13}$ Bila didapatkan gejala respirasi dan adanya gambaran radiologi yang abnormal, prosedur broncoscopi dapat dilakukan untuk mengambil beberapa polyp atau jaringan granulasi yang terlihal pada lumen bronchus untuk pemeriksaan histology dan kultur. ${ }^{13}$ Pada kasus ini pasien mengeluh adanya pembesaran kelenjar getah bening sejak 6 bulan yang lalu dengan diameter $3 \mathrm{~cm}$, batas kurang tegas, mobile terbatas dan padat kenyal. Dari pemeriksaan FNAB didapatkan hasil radang granulomatik sesuai tuberkulosis. 


\section{SLE}

Infeksi tuberkulosis pada SLE dapat disebabkan oleh mycobacterium tuberculosis (M.tb) dan non tuberculous mycobacterium (NTM). Infeksi M.tb cenderung terjadi pada awal perjalanan lupus dibandingkan infeksi NTM yang terjadi pada SLE yang berat. Infeksi MTB biasanya diakibatkan oleh reaktivasi infeksi laten atau reinfeksi. ${ }^{14}$

Penyakit autoimun merupakan kondisi umum yang ditandai autoreaktivitas respon imun sel $\mathrm{B}$ dan $\mathrm{T}$ yang abnormal. Beberapa faktor diantaranya perbedaaan genotipe, lingkungan hormonal dan faktor lingkungan berkontribusi terhadap perkembangan respon imun terhadap tubuh sendiri. Infeksi terbukti secara klinis dan eksperimental berperan sangat penting dalam induksi dan eksaserbasi SLE. ${ }^{14}$

Protein intraselular bakteri TB yaitu heat shock protein (HSP) 70kDa bersifat homolog dengan protein di sel pejamu sehingga dapat lolos dari mekanisme diskriminasi antigen self dan non-self melalui mimikri molekul (molecular mimicry) dan merangsang produksi autoantibody. Sebuah studi oleh Chodisetti et al (2012) menemukan bahwa terdapat epitop sel T cross reactive yang terbatas HLA alel kelas I dan II yang mirip dengan peptide protein mikrobakterial. Selain itu pada pasien TB diketahui mempunyai faktor reumatoid serta antibodi antinuklear yang merupakan ciri penyakit lupus. ${ }^{15}$ Prevalensi antibodi antinuklear (ANA) pada pasien TB bahkan mencapai 40\%. ${ }^{16}$ Studi oleh Azfar dan Islam mendapatkan bahwa antibodi pada pasien SLE sangat kuat mengenal native dsDNA dan antigen M.tb 85B (Ag85kDa). Sedangkan antibodi anti TB pada pasien TB sedikit mengenal native dsDNA. Pada pasien SLE dengan $\mathrm{TB}$, terdapat spesifisitas yang tinggi terhadap antigen native dsDNA dan M.tb 30kDa. ${ }^{16}$

Sebuah studi menyebutkan terdapat peningkatan risiko TB sebesar 23\% setiap gram prednisolon yang diberikan. Hal ini didukung oleh sebuah studi in vitro dimana kortisol dalam konsentrasi fisiologis, menghambat proliferasi sel yang dirangsang antigen mycobacterium dan menghambat produksi interferon- $\mathrm{k}$ pada pasien kontrol dan TB (8). Glukokortikoid mempunyai efek imunosupresif kompleks yang bersifat kualitatif dan kuantitatif. Glukokortikoid merangsang imunodesfisiensi seluler sehingga meningkatkan risiko infeksi virus, bakteri, jamur dan parasit. Efek antiinflamasi dan imunosupresi glukokortikoid disebabkan oleh adanya inhibisi NF- $\kappa \mathrm{B}$ dan faktor-faktor transkripsi lainnya dan mempengaruhi semual tipe sel yang terlibat dalam respon imun dan inflamasi. Peningkatan risiko infeksi tergantung pada dosis dan durasi penggunaan dan cenderung berisiko rendah pada pasien dengan dosis rendah meski dosis kumulatifnya tinggi. Penggunaan dosis glukokortikoid terendah yang diberikan malam hari dapat mengurangi risiko infeksi pada pasien autoimun. Meskipun tidak banyak yang meneliti penggunaan steroid dapat meningkatkan risiko penyakit TB baru atau reaktivasi TB, pemberian steroid tanpa pemberian obat anti tuberkulosis, dapat meningkatkan virulensi kuman M.tb. ${ }^{17}$

Diagnosis SLE pada pasien ini ditegakkan karena memenuhi 4 dari 11 kriteria The American College of Rheumatology tahun 1997 yaitu adanya oral ulcer, fotosensitiviti, arthralgia, malar rash. Penggunaan methyl prednisolon selama 11 bulan menyebabkan terjadinya imunosupressif sehingga meningkatkan risiko infeksi virus, bakteri, jamur dan parasit.

\section{KESIMPULAN}

Telah dilaporkan sebuah kasus seorang dewasa muda yang menderita SLE, TB MDR primer dan limfadenitis TB. Pasien datang dengan keluhan sesak napas dan batuk selama 2 bulan. Pada pemeriksaan fisik didapatkan pembesaran kelenjar getah bening submandibular. Tidak didapatkan peningkatan tekanan vena jugularis. Didapatkan pembesaran kelenjar getah bening di submandibula kanan dan kiri diameter $3 \mathrm{~cm}$, batas kurang tegas, mobile terbatas, padat kenyal. Foto thorax menunjukkan keradangan paru dapat merupakan proses spesifik, efusi pleura kiri minimal, kesimpulan: TB paru. Hasil FNAB colli radang granulomatosis sesuai TB. Pada pemeriksaan dahak -/-/+. Pada pemeriksaan Gene Xpert didapatkan M.tb positif, rifampisin resisten. Pasien dikategorikan sebagai TB MDR primer, dengan terapi: Pirazinamid $1500 \mathrm{mg}$, Ethambutol $800 \mathrm{mg}$, Kanamisin $750 \mathrm{mg}$, Levofloxacin $750 \mathrm{mg}$, Etionamide $500 \mathrm{mg}$, Cicloserin $500 \mathrm{mg}$, B6 $100 \mathrm{mg}$.

\section{DAFTAR PUSTAKA}

1. Perhimpunan Dokter Paru Indonesia. Tuberculosis: pedoman diagnosis dan penatalaksanaan di Indonesia. PDPI. 2011. 1-64.

2. Aditama TY, dkk. Tuberkulosis Pedoman Diagnosis dan Penatalaksanaan di Indonesia, PERPARI, Jakarta, 2006

3. Soedarsono. Multi-Drug Resistance (MDR) - TB. Buku Ajar Ilmu Penyakit Paru, Surabaya, 2010, 27-36.

4. Soedarsono. Genesis of MDR TB : clinically and program aspect. Majalah Kedokteran Respirasi. Vol. 1.2010. 12-18.

5. Agraz R, Balchin D, Bayona J. Drug Resistant Tuberculosis a survival guide for clinicians. Edisi 2. 2008. 1-143.

6. Program Pengendalian TB Nasional Indonesia. Draf Pedoman Diagnosa dan pengobatan programatik TB-MDR(MDR) dan TBXDR(XDR) dalam konteks proyek uji pendahuluan Green Light Committee, Juni 2008.

7. Powell DA, (2002). Tuberculous Lymphadenitis In: Tuberculosis and nontuberculosis mycobacterial infection $4^{\text {nd }}$ edition. Eds: Schlossberg,WB Saunders Company, Philadelpia. Pp: 186-93.

8. Prabu VNN, S Agrawal. Systemic lupus erythematosus and tuberculosis: a review of complex interaction of complicated disease. Postgrad Med 2010; 56: 244-250.

9. Riyanto BS, Wilhan. Management of MDR TB Current and Future dalam Buku Program dan Naskah Lengkap Konferensi Kerja Pertemuan Ilmiah Berkala. PERPARI.Bandung. 2006.

10. Wallace RJ, Griffith DE. Antimycrobial Agents in Kasper DL, Braunwald E (eds), Harrison's Principles of Internal Medicine, 16th ed. McGraw-Hill. New York. 2004.

11. Helmia Hasan. Tuberculosis Paru. Buku Ajar Ilmu Penyakit Paru, Surabaya, 2010, 9-22. 
12. Alsagaff H, Mukty A, 2002. Dasar-dasar ilmu penyakit paru. Edisi kedua Airlangga University Press, Surabaya pp. 73-109.

13. Hopewell PC (2000). Tuberculosis and other mycobacterium disease. In: Text book of respiratory medicine. Eds: Murray SF, Nadel JA, WB Sunders Company, Philadelphia. Pp: 1043-96.

14. Arce-Salinas CA, Villaseñor-Ovies P. Infection and systemic lupus erythematosus. In: Almoallim H. ed. Systemic Lupus Erythematosus. Croatia: In Tech; 2012. pp. 407-428.
15. Tasneem S, Islam N, Ali R. Crossreactivity of SLE autoantibodies with $70 \mathrm{kDa}$ heat shock proteins of Mycobacterium tuberculosis. Microbiol Immunol 2001; 45: 841-846.

16. Chodisetti SB, Rai PK, Gowthaman U, Pahari S, Agrewala JN. Potential T cell epitops of Mycobacterium tuberculosis that can instigate molecular mimicry against host: implication in autoimmune pathogenesis. BMC Immunol 2012; 13: 13.

17. Mohd A, Goh EML, Chow SK, Looi LM, Yeap SS. Tuberculosis or systemic lupus erythematosus. A diagnostic and therapeutic dilemma. Southeast Asian J Trop Med Public Health 2003; 34: 361-364. 